\title{
Assessing the Self-care Status in Older Adults Diagnosed with Heart Failure and Hospitalized in the Cardiovascular Intensive Care Units of the Public Hospitals in the East of Guilan, Iran (2020)
}

\author{
Leila Zahed Nakhjiri ${ }^{1}$, Azar Darvishpour ${ }^{2}$, Parand Pourghane ${ }^{3}$, Bahareh Gholami Chaboki ${ }^{4}$
}

\begin{abstract}
Background \& Aims: One of the most common diseases during old age is cardiovascular disease. Heart failure is the leading cause of death, disease, hospitalization, and poor quality of life. There are different approaches for controlling heart failure, including self-care, and adherence to self-care behaviors in patients suffering from this disease is very important. People with effective self-care have a better quality of life, and mortality and readmission rates are lower among these people than those with poor self-care. Medication adherence, diet adherence, rest, improving sleep quality and life quality, knowing how to control emotions, and self-care could help control the complications and problems associated with this disease. Meanwhile, knowing how to perform self-care is very important. Despite the importance of self-care in positive health outcomes, many patients with heart failure have inadequate self-care behaviors. Considering the role of nurses in health promotion and instruction of self-care behaviors, they can plan interventions to promote the patients' self-care behaviors and consequently the quality of life in patients diagnosed with heart failure. The present study aimed to determine selfcare status in older adults diagnosed with heart failure.

Materials \& Methods: This article reports part of the results of a larger cross-sectional study. The study population consisted of the elderly with heart failure hospitalized in the cardiovascular intensive care units of East Guilan public hospitals in 2020. A sample of 125 patients was selected from the population via convenience sampling. The sample of the study met the inclusion and exclusion criteria. Inclusion criteria were: age 60 years and older, heart failure based on clinical signs, electrocardiography (ECG) and echocardiography showing an ejection fraction of less than $40 \%$, functional class II to IV based on the patient medical file and the approval of a cardiologist, the ability to communicate, and informed consent to participate in the study. Patients with severe mental or cognitive impairments, history of neurological problems, cerebrovascular accidents, transient ischemic attack, short-term memory impairment or dementia, mental instability (according to medical records), inability to speak, auditory and visual impairments, and Charlson comorbidity index of 1-2 were not included in the study, and the exclusion criteria included incomplete completion of the questionnaire and unwillingness to continue collaborating in the study. The research instruments included demographic characteristics questionnaire and the self-care of heart failure index (SCHFI) questionnaire. Cronbach's alpha was used to check the reliability of the SCHFI in the present study which was 0.82. Sampling lasted from late May to December 2020. Having obtained permission from the ethics committee of Guilan University of Medical Sciences and relevant officials, the researcher referred to the mentioned medical centers, selected the research units, introduced himself, provided sufficient explanations about the purpose of the research, obtained their written consent, and distributed the questionnaires to be completed during the interview. Data were analyzed using descriptive statistics (frequency, mean, and standard deviation) in SPSS 16.

Results: The analysis of the questionnaires revealed that most patients (55.2\%) were male, aged 75-90 (54.4\%), married (57.6\%), with average monthly income (60\%), and illiterate $(72 \%)$. The findings showed that the patients

\footnotetext{
1. Department of Nursing, Zeynab (P.B.U.H) School of Nursing and Midwifery, Guilan University of Medical Sciences, Rasht, Iran

2. Department of Nursing, Zeynab (P.B.U.H) School of Nursing and Midwifery Guilan University of Medical Sciences, Rasht, Iran (Corresponding author) Tel: +98-1342536262 Email: darvishpour@gums.ac.ir

3. Department of Nursing, Zeynab (P.B.U.H) School of Nursing and Midwifery, Guilan University of Medical Sciences, Rasht, Iran

4. Department of Biostatistics, Shahid Beheshti University of Medical Science, Tehran, Iran
} 
of the study obtained $67.16 \pm 10.96$ for self-care items, $28.94 \pm 4.39$ for self-care maintenance, $17.98 \pm 3.96$ for self-care management, and $20.49 \pm 4.05$ for self-care confidence. The scores of most participants were satisfactory in terms of total self-care $(75.2 \%)$ and its subscales including self-care maintenance (59.2\%), self-care management $(69.6 \%)$, and self-care confidence (82.4\%). The optimal self-care status was considered satisfactory in terms of adherence to self-care behaviors, self-care management, and self-care maintenance, respectively. The optimal self-care status belonged to self-care confidence, self-care management, and self-care maintenance, respectively. Regarding the items on the self-care maintenance subscale, the best self-care behaviors were selfprotection measures to prevent illnesses, a low-salt diet, and regular visits to a physician or a health center to assess heart condition, respectively, and the most inappropriate self-care behaviors were related to exercise and daily weight.

Conclusion: The findings showed that the self-care status of patients with heart failure is generally satisfactory. Despite the study findings, it is essential to pay more attention to nursing care and treatments that promote selfcare behaviors in older adults especially in self-care behaviors related to exercise and daily weighing. It is suggested that hospitals offer educational classes to improve the knowledge, attitude, and self-care practices in patients with heart failure.

Keywords: Elderly, Heart failure, Self-care

\section{Conflict of Interest: No}

How to Cite: Zahed Nakhjiri L, Darvishpour A, Pourghane P, Gholami Chaboki B. Assessing the Self-care Status in Older Adults Diagnosed with Heart Failure and Hospitalized in the Cardiovascular Intensive Care Units of the Public Hospitals in the East of Guilan, Iran (2020). Iran Journal of Nursing. 2021; 34(129): 67-81.

Received: 13 Jan 2021

Accepted: 14 Apr 2021 


\title{
وضعيت خودمراقبتى در سالمندان مبتلا به نارسايى قلبى بسترى در بخشهاى مراقبت ويزه

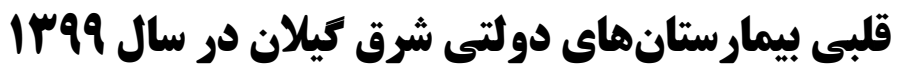

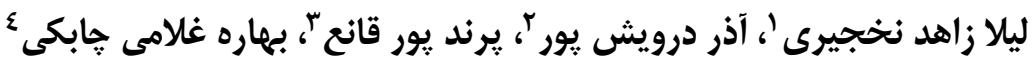

جكيله

زمينه و هدف: نارسايى قلبى دليل اصلى مرگ، بيمارى، بسترى شدن در بيمارستان و كيفيت يايين زندگى است. كزينهاى زيادى براى كترل نارسايى قلبى وجود دارد كه خودمر اقبتى يكى از آنها است. با وجود اهميت خودمراقبتى در نتايج مثبت سلامتى، بسيارى از بيماران مبتلا به نارسايى قلبى رفتارهاى

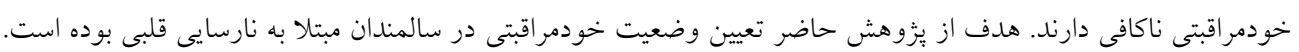
روش بررسى: اين مقاله بخشى از نتايج يك مطالعه مقطعى بزركتر را گزارش مىنمايد. جامعله يُزوهش شامل سالمندان مبتلا به نارسايى قلبى بسترى در

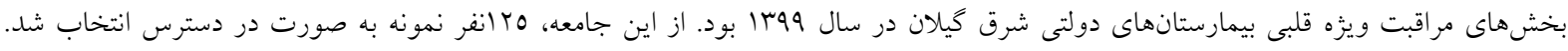

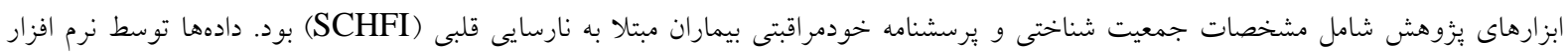

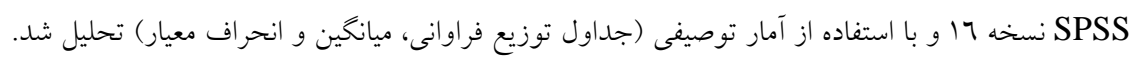

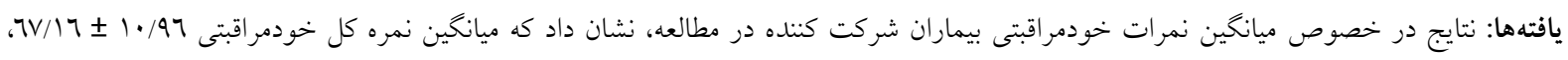

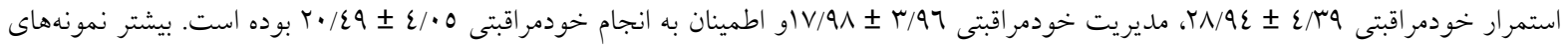

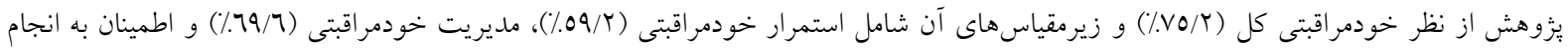
خودمراقبتى (ع/^/^/) داراى وضعيت مطلوب بودند. بهترين وضعيت خودمراقبتى مطلوب به ترتيب در ابعاد اطمينان به انجام خودمراقبتى، مديريت خودمراقبتى و استمرار خودمراقتى بودند.

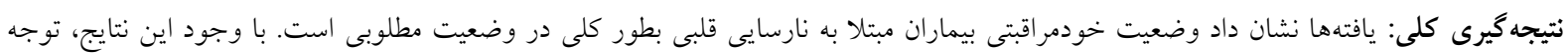
بيشتر در مراقبتهاى يرستارى و درمانى جهت ارتقاء و بهبود وضعيت خودمراقبتى در سالمندان خصوصاً در رفتارهاى خودمراقبتى مربوط به انجام ورزش و توزين روزانه ضرورى به نظر مىرسد. كليدوازهها: سالمند، نارسايى قلبى، خودمراقبت تعارض منافع: وجود ندارد.

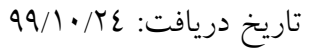

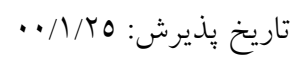

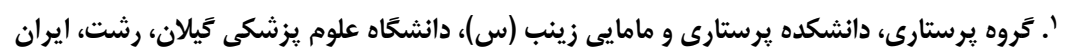

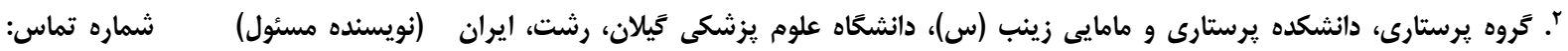
E-mail: Darvishpour@gums.ac.ir +911)

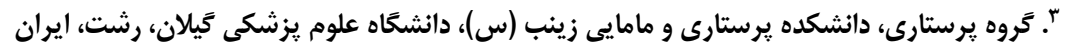

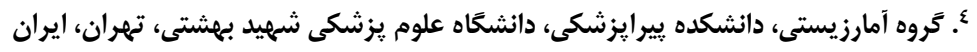


جامعه و وييرشدن جمعيت، در آيندهاى نزديك بر شيوع

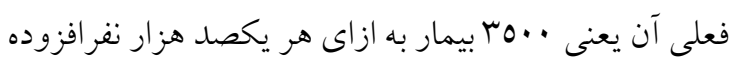

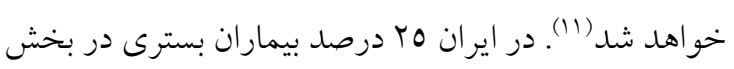
هاى قلب دهار نارسايى احتقانى قلبى هستند (Ir). بيماران مبتلا به دليل بروز ضعف قلب و اختلال دار در عملكرد

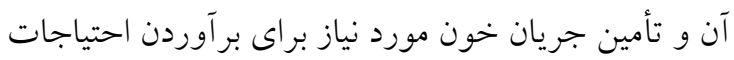
متابوليك اعضا و بافتهاى بدن با مشكل مواجه مىشوند

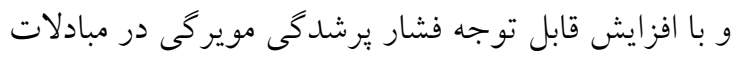

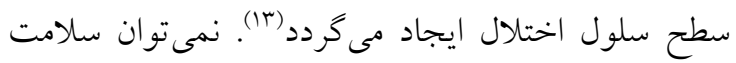
كامـل را بـه بيمار ان نارسايى قلبى بركرداند اما علايم بيمار را با مداخلات دارويى و غير دارويى مىتوان كنترل كرد. يكسى از مـداخلات غيـر دارويسى براى كنترل اين بيمارى

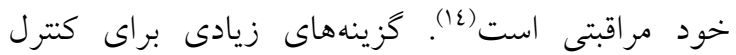
نارسايى قلبى وجود دارند كه خودمراقبتى يكى از آنها

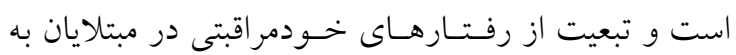
اين بيمارى از اهـمـيـت بـهـ سـز ايسى برخوردار است (10).

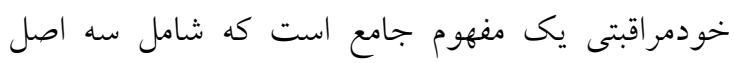
كليدى اسـت: حفظ و اسـتمرار خــودمراقبتى ( self care

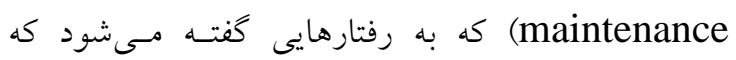
روزانه توسط بيماران مبتلا به نارسايى انجام مىشود تا بـهـ حفظ ثبات فيزيولوزيكى و جلوكيرى از عوارض برسند. مـديريت خـودمراقبتى (self care management)

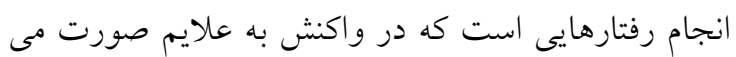

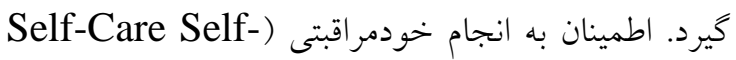

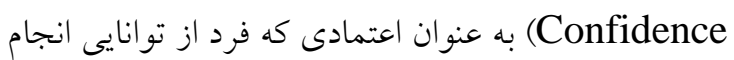

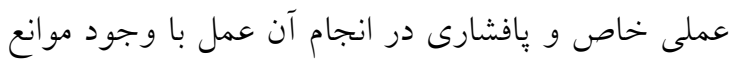

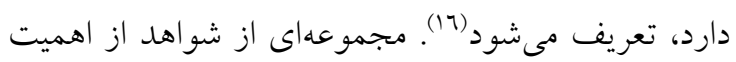
خودمراقبتى در نارسايى قلبى براى جلو گيرى از يِيامدهاى بيمار و بهبود كيفيت زندگى مرتبط با سلامت مطرح

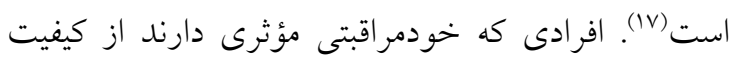
زندكى بهتر، ميز ان مرگ و بسترى مجدد كمترى در مقايسه با افرادى كه خودمراقبتى ضعيف دارند برخوردار

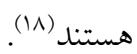

مقدمه سالمندى دورهاى اجتناب نايذير از زندكى است و هر

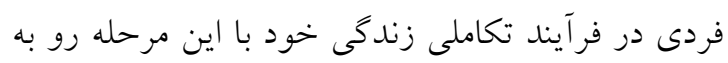

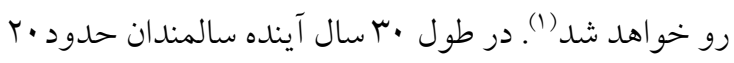
درصد از جمعيت جهان را تشكيل مىدهند (r). سازمان

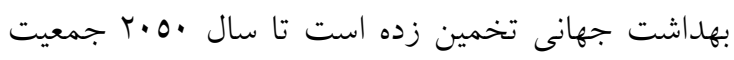

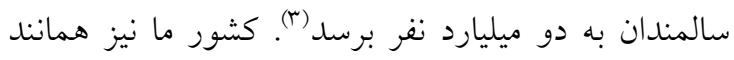

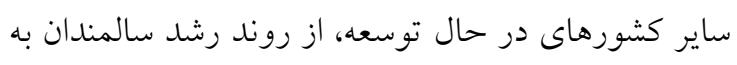

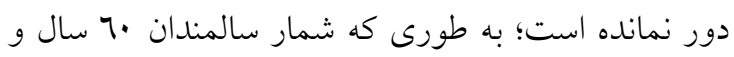
بالاتر در آخرين سرشمارى

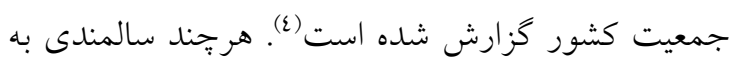
خودى خود بيمارى محسوب نمى گردد، اما با افزايش سن، احتمال ابتلا به حداقل يكى از بيمارىهاى مزمن افزايش

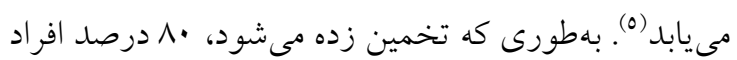
سالمند حداقل به يك بيمارى مزمن و (1\%) به دو بيمارى مزمن مبتلا هستند (7). يكى از بيمارىهاى شايع در اين دوره سنى، بيمارىهاى قلبى عروقى است. بيمارىهاى قلبى عروقى تا به امروز

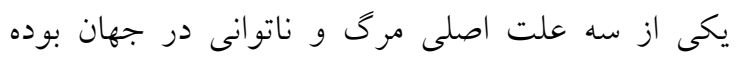
است (V). نارسايى قلبى دليل اصلى مرگ، بيمارى، بسترى

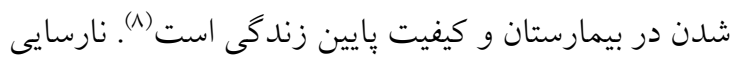
مزمن قلبى (CHF:Chronic Heart Failure) سندرم بالينى بيّيدهاى است كه به عنوان اختلالى مزمن بيش

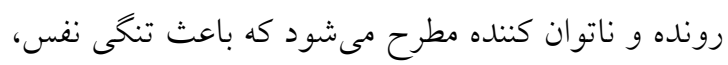

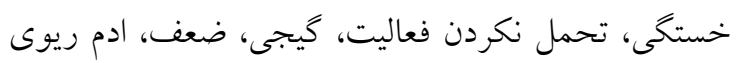
اندامها، درد قفسه سينه و تهي قلب در بيمار شده در نهايت

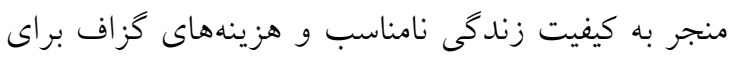

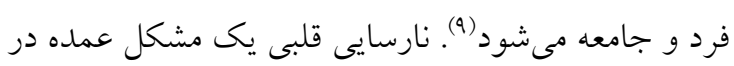
سلامت عمومى است. عامل اصلى نارسايى قلبى، فشار

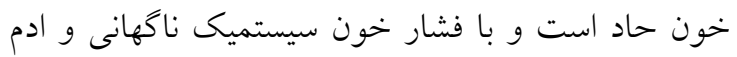
ريوى مشخص مى شود. باتوفيزيولوزى فشارخون بالا در نارسايى حاد قلبى در درجه اول توسط يك رابطه بطنى -

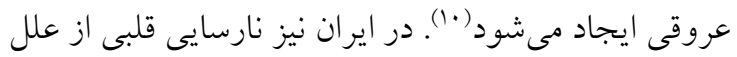

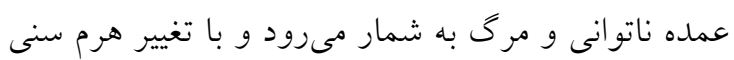


توان با شناسايى اين رفتارها مداخلات برنامه ريزى شده اى براى ارتقاء سطح رفتارهاى خودمراقبتى و در نتيجه بهبود كيفيت زندگى بيماران مبتلا به نارسايى قلبى تدوين

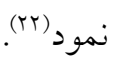
با وجود مطالعات انجام شده در زمينه وضعيت خود مر اقبتى بيماران مبتلا به نارسايى قلبى، مرورى بر متون حكايت از

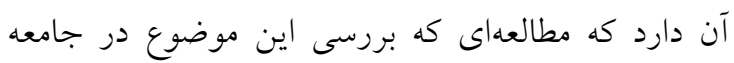
سالمندان استان كيلان به عنوان سالمندترين استان كشور بيردازد، انجام نشده است و با توجه به روند صعودى افزايش جمعيت سالمندان در كشور و شيوع بيمارىهاى قلبى - عروقى و خصوصاً نارسايى قلبى و با در نظر داشتن اين كه با شناسايى وضعيت خود مراقبتى و ابعاد آن، به كونهاى سازمان يافتهتر مىتوان به طراحى مداخلات بيشخيرانه مؤثر براى اين گروه سنى برداخت، بزّوهش حاضر با هدف تعيين وضعيت خودمراقبتى در ابعاد استمرار رفتار، مديريت و اطمينان به انجام خودمراقبتى صورت كرفت.

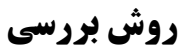

اين مقاله بخشى از نتايج يكى مطالعه مقطعى بزر كتر در سال

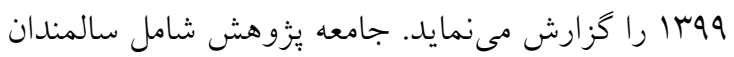
مبتلا به نارسايى قلبى بسترى در بخش هاى مر اقبت ويزه

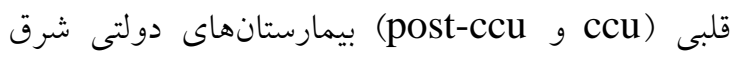
كيلان (وابسته به دانشگاه علوم يزشكى كيلان) بود كه از

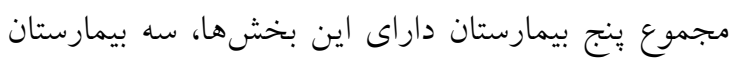

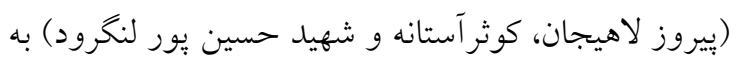

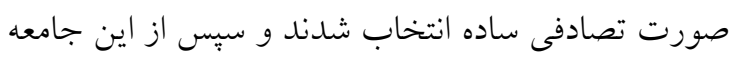
نمونهاى به حجم 1Y ا نفر به صورت در دسترس انتخاب

براى تعيين حجم نمونه، با استناد به مطالعه

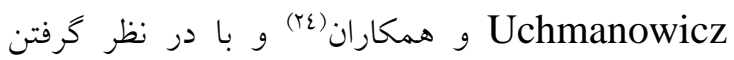
ضريب اطمينان 90 درصد و توان آزمون •م درصد، حجم نمونه ع|النفر محاسبه كرديد كه با احتساب •ا درصد
با وجود اهميت خودمراقبتى در نتايج مثبت سلامتى، بسيارى از بيماران مبتلا به نارسايى قلبى رفتارهاى

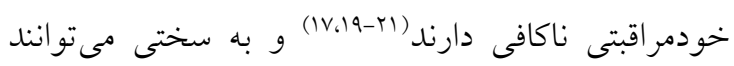
توصيههاى مراقبت از خود را دنبال كنند. اين فقدان يايبندى

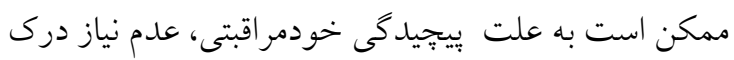

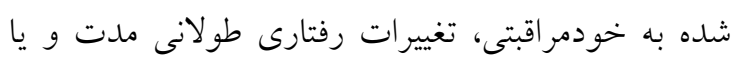

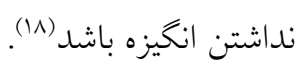
مطالعات متعددى به بررسى وضعيت خودمراقبتى در

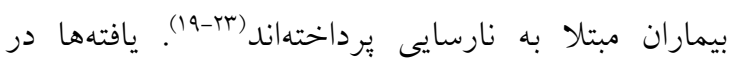

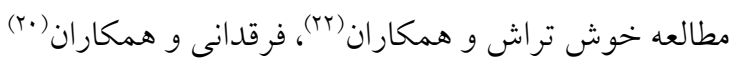
و باقرى ساوه(r) نشان داد وضعيت خودمراقبتى بيماران مبتلا به نارسايى قلبى، در سطح متوسط است. در برخى از مطالعات ذكر شده است كه حداقل •0 درصد بيماران مبتلا به نارسايى قلبى از توصيههاى درمانى خود تبعيت نمى كنند و همين امر منجر به بسترى شدن مجدد آنها

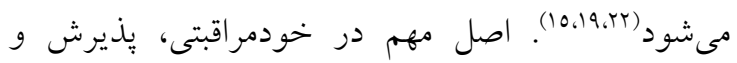

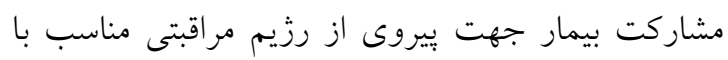
شرايط مزمن بيمارى و انجام رفتارهاى خودمراقبتى

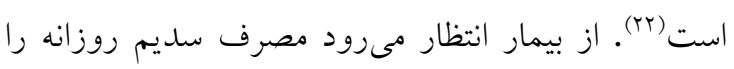
محدود كند؛ در برنامههاى فعاليتى روزانه شركت كند؛ از

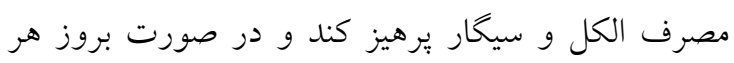
كونه علايم غير طبيعى به مركز درمانى مراجعه كند(Tr(). رعايت رزيم دارويى و غذايى، استراحت، ارتقاى كيفيت خواب و كيفيت زندكى، شناخت نحوهى كنترل هيجانات و شيوه خودمراقبتى از جمله مواردى است كه در كنترل عوارض و مشكلات اين بيمارى كمك كننده است كه در اين ميان شناخت نحوه مراقبت از خود از اهميت بسزايى برخوردار است (19). بسيارى از دلايلى كه منتهى به تبعيت نكردن از درمان و تشديد نارسايى قلبى مىشود با استفاده

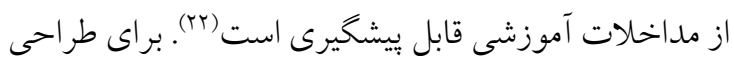

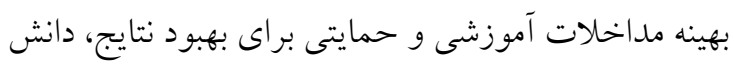
بيشترى در مورد رفتارهاى خودمراقبتى در بيماران مبتلا به نارسايى قلبى لازم است (rr). با توجه به نقش برستاران در ارتقاء سطح سلامت و آموزش رفتارهاى خود مراقبتى، مى لى ليك 
مكانى، ثبت سه كلمه، توجه و محاسبه، يادآورى سه كلمه،

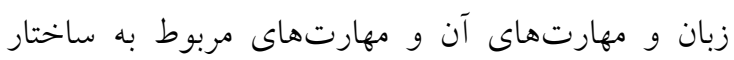

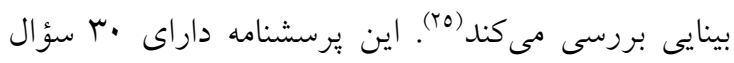

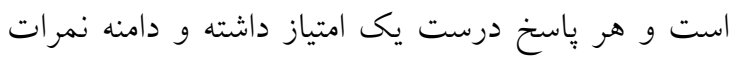

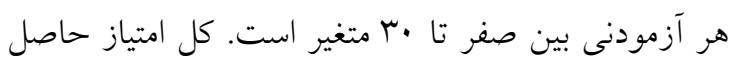

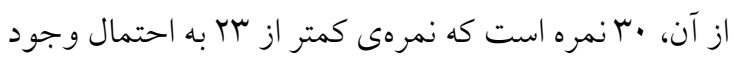
اختلال شناختى اشاره مى كند (Tr).

- يُرسشنامه سنجش وضعيت خودمراقبتى بيماران مبتلا به نارسايى قلبى: اين يرسشنامه توسط Riegel و

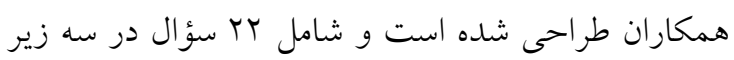

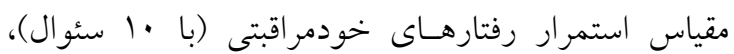

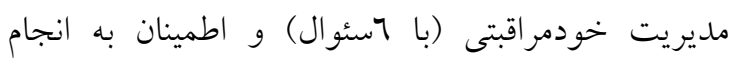

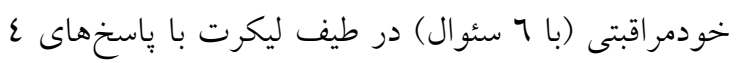

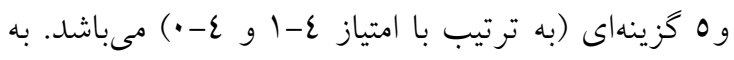
اين ترتيب محدوده نمرات در زير مقياس استمرار

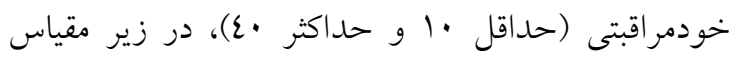

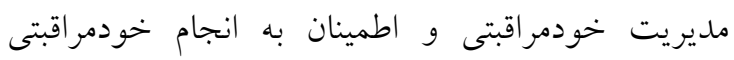

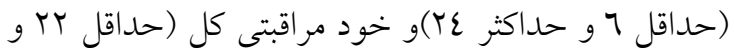

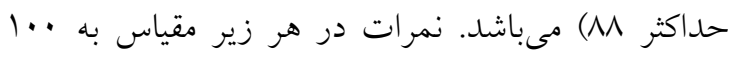
تبديل مىشود كه نمرههاى بالاتر نشان دهنده خودمر اقتى

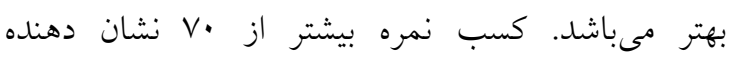

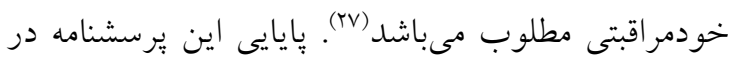

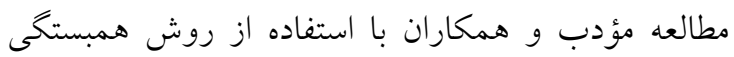

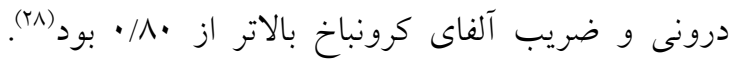

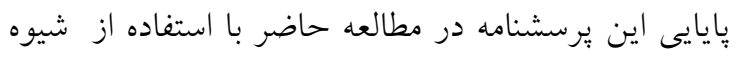

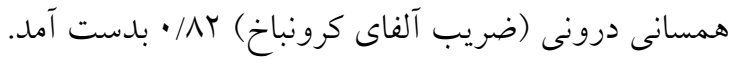

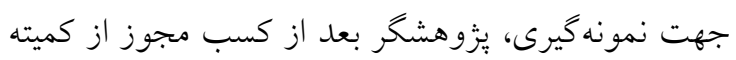

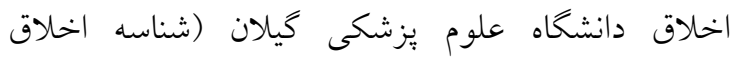

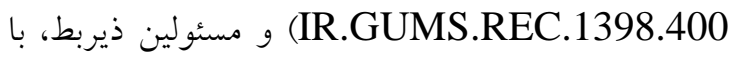
مراجعه به مراكز درمانى مذكور و انتخاب واحدهاى مورد

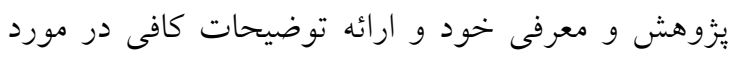

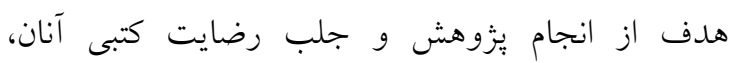

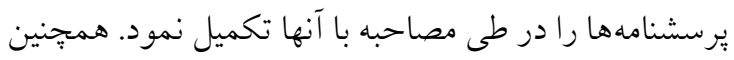

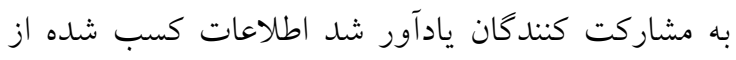

احتمال ريزش، حجم نمونه نهايى 1ro نفر در نظر كرفته

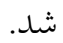
معيارهاى ورود به مطالعه عبارت بودند از: دارا بودن سن •7. سال و بالاتر، ابتلا به بيمارى نارسايى قلبى بر اساس علائم

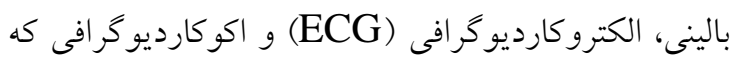
نشان دهنده كسر تخليه كمتر از •عـ٪ و كلاس عملكردى

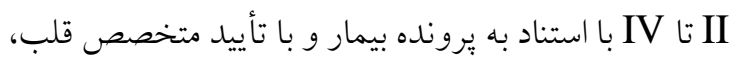

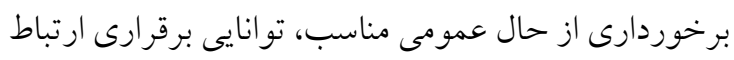

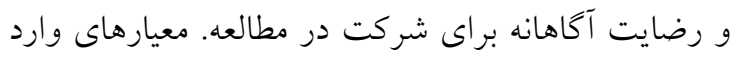

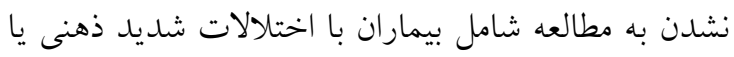
شناختى (كسب نمره كمتر از Y در يرسشنامه معاينه MMSE: Mini-Mental مختصر وضعيت شناختى State Examination

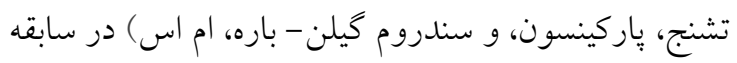

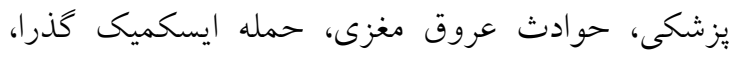
اختلال در حافظه كوتاه مدت يا دمانس و نداشتن ثبات

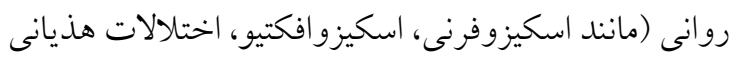

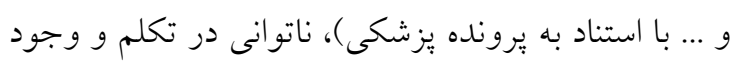

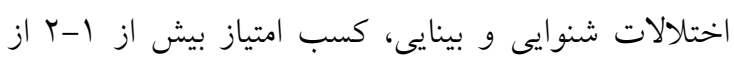

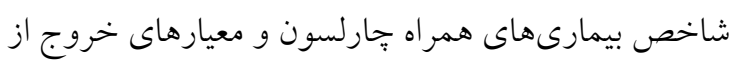

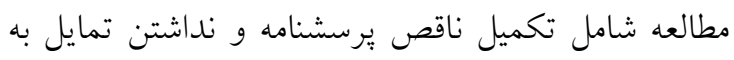

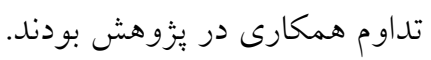

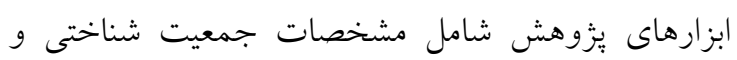

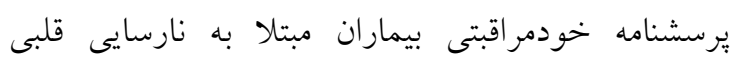
(SCHFI:Self-care Heart failure Index) در ادامه در مورد آن توضيح داده مىشود.

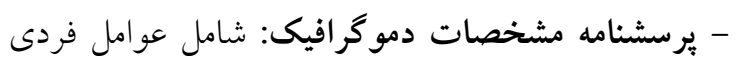

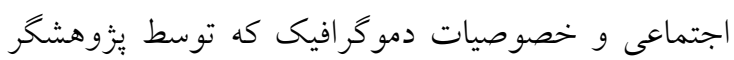
تنظيم شده و مشتمل بر سؤالاتى از قبيل سن، جنس، ونس وضعيت تأهل، ميزان تحصيلات، ميزان درآمد مى باشد.

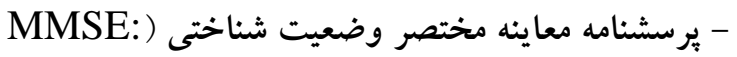
Mini-Mental State Examination يكى ابزار غربالكرى است كه شدت نقص شناختى و تغييرات شناختى را در شش زمينه جهتيابى زمانى و 
نسخه 17 و با استفاده از آمار توصيفى (جداول توزيع فراوانى، ميانخين و انحر اف معيار) تحليل شد.

\section{بافتهها}

نتايج در ارتباط با ويزگى هاى دموكر افيك سالمندان مبتلا به نارسايى قلبى بسترى در بيمارستانهاى شرق كيلان نشان

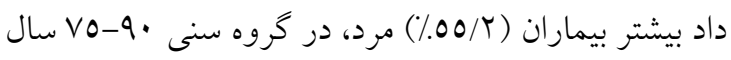

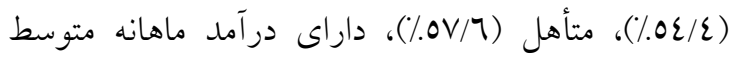

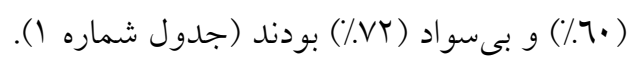

آنها كاملاً به صورت محرمانه خو اهد ماند و هر زمانى كه

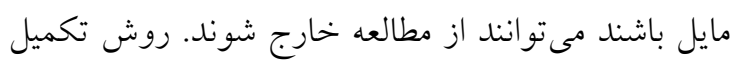

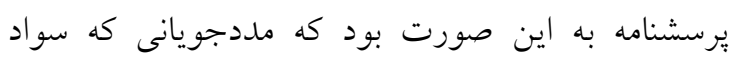

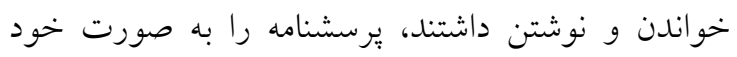
كزارش دهى تكميل مى كردند و براى مددجويانى كه سواد نداشتند، سؤالات توسط محقق برسيده مىشد و ورياسخ آنها توسط محقق در برسشنامه ثبت مىشد. نمونه كيرى در بازه

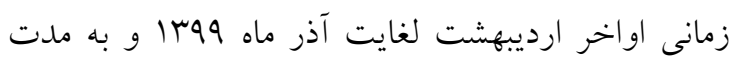

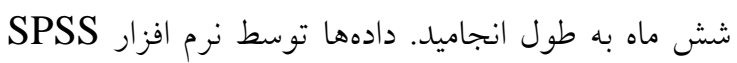

جدول شماره ا: ويزَّى هاى جمعيت شناختى سالمندان مبتلا به نارسايى قلبى بسترى در بيمارستانهاى شرق كَيلان در سال هوسا $(n=1$ ro $)$

\begin{tabular}{|c|c|c|c|c|c|c|c|}
\hline درصد & تعداد & & متغير & درصد & تعداد & \multicolumn{2}{|c|}{ متغير } \\
\hline VT & 9. & بيسو اد & سطح & $\varepsilon 0 / 7$ & oV & $7 \cdot-\sqrt{ } \varepsilon$ & سن (سال) \\
\hline $10 / r$ & 19 & ابتدايى & تحصيلات & $0 \varepsilon / \varepsilon$ & $u$ & vo-9. & \\
\hline$V / r$ & 9 & سيكل & & $00 / r$ & 79 & مرد مرد & جنسيت \\
\hline $0 / 7$ & v & دانشخاهى & & $\varepsilon \varepsilon / \Lambda$ & 07 & زن ان & \\
\hline 7. & vo & 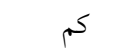 & ميزان درآمد & $0 V / 7$ & VY & متأهل با همسر & \\
\hline$r q / r$ & $\varepsilon 9$ & متوسط & ماهانه & $\cdot / \wedge$ & 1 & متأهل جدا از همسر & تأهل \\
\hline$\cdot / \Lambda$ & 1 & كافى & & $\cdot / 1$ & 1 & مطلقه & \\
\hline & & & & $\varepsilon \cdot / \wedge$ & 01 & همسر فوت شده & \\
\hline
\end{tabular}

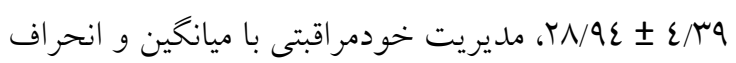

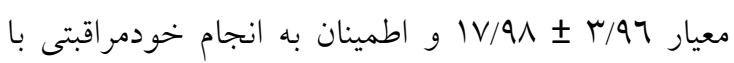

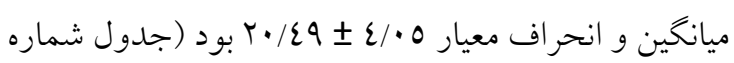

در خصوص ميانخين نمرات خودمراقبتى كل و زيرمقياس هاى آن در بيماران شركت كننده در مطالعه، نتايج نشان داد كه ميانخين نمره كل خودمراقبتى بيماران TV/IT استمرار خودمراقبتى با ميانخين و انحراف معيار

جدول شماره r: شاخصهاى مركزى و يراكندتى امتيازات خودمراقبتى كل و زيرمقياسهاى آن در واحدهاى مورد بزوهش

\begin{tabular}{|c|c|c|c|c|c|c|c|c|}
\hline \multicolumn{4}{|c|}{ نمره برمبناى · تا ... } & \multirow{2}{*}{ حداكثر } & \multirow{2}{*}{ حداقل } & \multirow{2}{*}{ انحر اف معيار } & \multirow{2}{*}{ ميانكين } & \multirow{2}{*}{ نمره خودمر اقبتى } \\
\hline 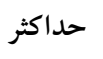 & 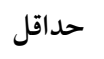 & انحر اف معيار & ميانخين & & & & & \\
\hline 90 & $\varepsilon Y / 0$ & 1.199 & $v \cdot / 7$ & ru & iv & $\varepsilon / \pi q$ & TN/TE & استمر ار خودمر اقتىى (•l-•ع) \\
\hline $1 \ldots$ & ro & 17/or & ve/qr & $r \varepsilon$ & 7 & $r / 97$ & $\mid V / 9 \Lambda$ & مديريت خودمر اقبتى (T- ع) \\
\hline $1 \cdots$ & ro & $17 / 91$ & $10 / \mathrm{rV}$ & $r \varepsilon$ & 7 & $\varepsilon / \cdot 0$ & $r \cdot / 29$ & اطمينان به انجام خودمراقبتى (7- (Y) \\
\hline $90 / 20$ & $r q / v v$ & $11 / N 1$ & Vo/NI & $\wedge \vee$ & r & $1 . / 97$ & $7 V / 17$ & خودمراقبتى كل (M-YYM) \\
\hline
\end{tabular}


بهترين وضعيت خودمراقبتى مطلوب به ترتيب در بعد

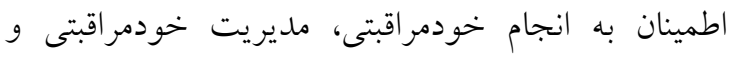

استمر ار خودمراقبتى بود (نمودار شماره ()).
بيشتر واحدهاى يزوهش (TO/T/) از نظر خودمراقبتى كل

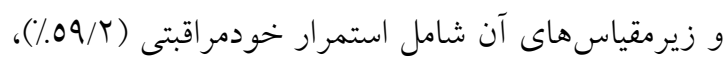

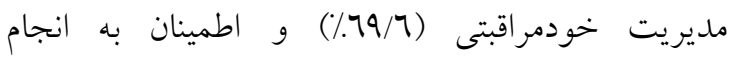

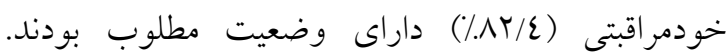

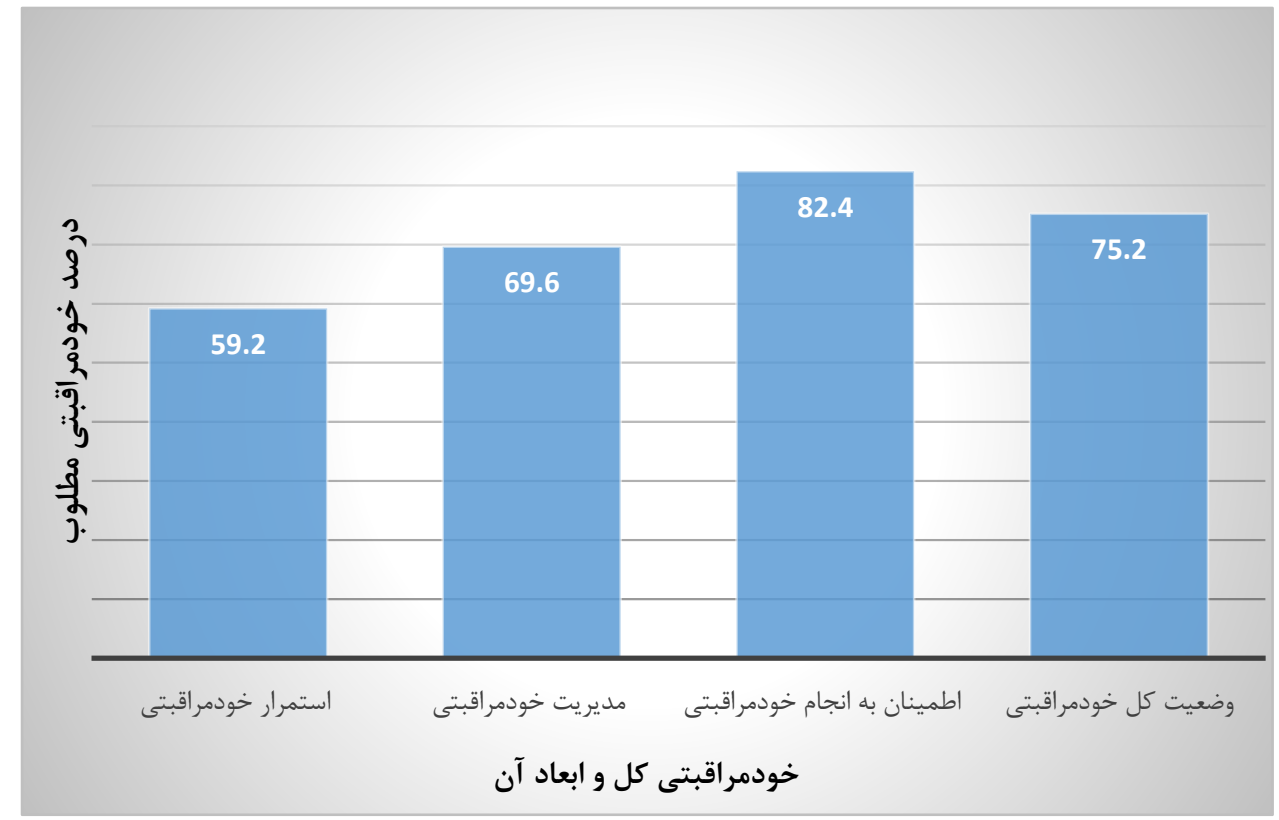

نمودار شماره ا: درصد خودمراقبتى مطلوب بطور كلى و به تفكيك زيرمقياسها در واحدهاى مورد بزوهش

اول (آيا روزانه خودت راوزن مى كنيد؟) بود. نكته قابل توجه در بررسى كويهها در اين زيرمقياس آن بود كه با روديا وجود آنكه بيشتر اين بيماران (N/N/N) روشى براى يادآورى زمان خوردن داروهاى قلبى داشتند، درصد قابل

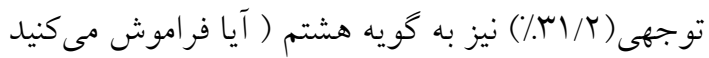

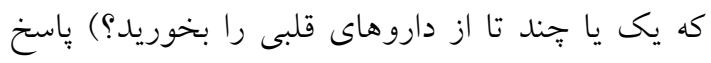
هميشه را ذكر نمودند (جدول شماره ب).

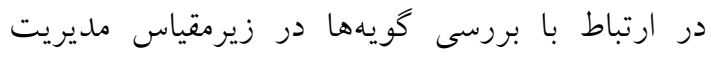

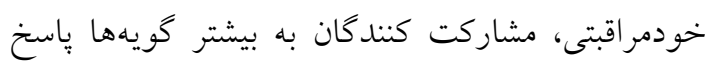

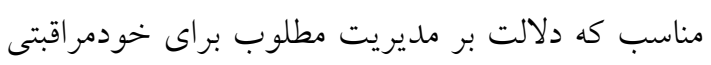
آنان دارد، دادند (جدول شماره ع).
در ارتباط با بررسى كويهها در زيرمقياس استمرار خودمراقبتى، بهترين رفتارهاى خودمراقبتى به ترتيب

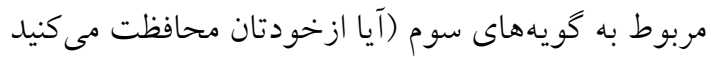

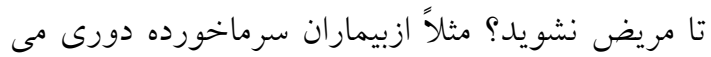
كنيد؟)، گويه دهم (آيا روشى براى يادآورى زمان خوردن

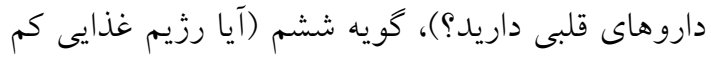

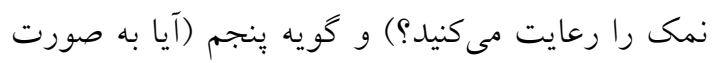

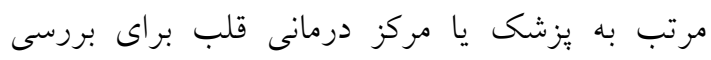

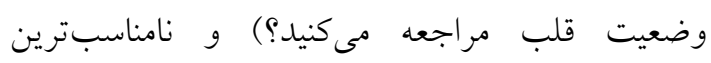

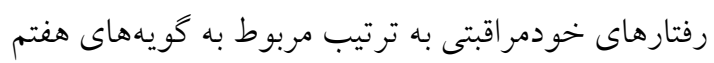
(آيا حداقل نيم ساعت در روز ورزش مى كنيد؟) و كويه 
جدول شماره "ّ: توزيع فراوانى باسخ به تويههاى زيرمقياس استمرار خودمراقبتى

\begin{tabular}{|c|c|c|c|c|c|}
\hline هميشه & 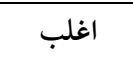 & بعضى وقتها & هر كز يا به ندرت & كويه & رديف \\
\hline تعداد & ت تعداد & ت تعداد & تعداد (درصد) & & \\
\hline ） (درصد) & ） & (درصد) & & & \\
\hline$(7 / 2) \wedge$ & $(1 T / 7) I V$ & $(\Sigma V / T) \circ 9$ & $(r Y / \Lambda) \varepsilon$ & آيا روزانه خود را وزن مى كنيد؟ & 1 \\
\hline$(\varepsilon \cdot / \cdot) 0$. & $(17 \cdot \cdot) r \cdot$ & $(Y \cdot / \Lambda) Y\urcorner$ & $(r r / r) r q$ & آيا قوزى باى خود را براى وجود ورم نخاه مى كنيد؟ & r \\
\hline$(97 / 7) \wedge \vee$ & $(Y I / 7) T V$ & $(7 / \varepsilon) \wedge$ & $(r / \Sigma) r$ & آيا ازخودتان محافظت مى كنيد تا مريض نشويد؟ مثلاً ازبيماران & r \\
\hline$(\varepsilon 1 / 7)$ or & $(10 / r) 19$ & $(r Y / \Lambda) \varepsilon 1$ & $(1 \cdot / 2) \mid r$ & آيا فعاليتهاى بدنى روزمره عادى مثل انجام امور منزل را انجام مى دهيد؟ & $\varepsilon$ \\
\hline$(7 T / \varepsilon) \wedge r$ & $(17 / \Lambda) r \mid$ & $(1 \cdot / \varepsilon) 1 r$ & $(\mathrm{~T} / \varepsilon) \wedge$ & 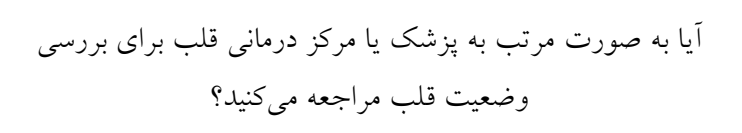 & $\circ$ \\
\hline$(79 / 7) \wedge \vee$ & $(1 r / 7) i v$ & $(0 / 7) \vee$ & $(11 / \Gamma) \mid \varepsilon$ & آيا رزيم غذايى كم نمك را رعايت مى كنيد؟ & 1 \\
\hline$(r / \varepsilon) r$ & $(\Lambda / \cdot))$ & $(T V / r) r \varepsilon$ & $(7 T / 2) \vee \wedge$ & آيا حداقل نيم ساعت در روز ورزش مى كنيد؟ & $v$ \\
\hline$\left(r_{1 / T}\right) r_{q}$ & $(\Sigma / \Lambda)\urcorner$ & $(7 / \varepsilon) \wedge$ & $(O V / T) V Y$ & آيا فراموش مى كنيد كه يك يا جند تا از داروهاى قلبى را بخوريد؟ & $\wedge$ \\
\hline$\left.\left(\sum N / \Lambda\right)\right\rceil 1$ & $(r \varepsilon / \cdot) r \cdot$ & $(1 Y / \cdot) 10$ & $(10 / Y) 19$ & 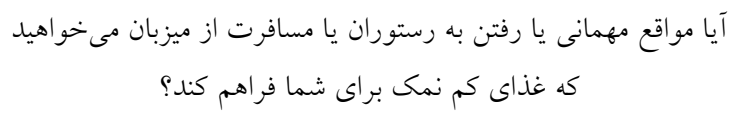 & 9 \\
\hline$(V T / \Lambda) 91$ & $(I V / 7) r Y$ & $(7 / 2) \wedge$ & $(r / \Gamma) \varepsilon$ & آيا روشى براى يادآورى زمان خوردن داروهاى قلبى داريد؟ & $1 \cdot$ \\
\hline
\end{tabular}

جدول شماره ع: توزيع فراوانى ياسخ به تويه هاى زيرمقياس مديريت خودمراقبتى

\begin{tabular}{|c|c|c|c|c|c|c|}
\hline \multirow{2}{*}{\multicolumn{2}{|c|}{ خيلى احتمال دارد }} & \multirow{2}{*}{ احتمال دارد } & \multirow{2}{*}{ تا حدى احتمال دارد } & اصلاً احتمال & \multirow{3}{*}{ كويه } & \multirow{3}{*}{ رديف } \\
\hline & & & & ندارد & & \\
\hline \multicolumn{2}{|c|}{ تعداد (درصد) } & تعداد (درصد) & تعداد (درصد) & تعداد (درصد) & & \\
\hline \multicolumn{2}{|c|}{$(79 / 7) \wedge \vee$} & $(10 / r) 19$ & $(1 \cdot / 2) 14$ & $(\Sigma / \Lambda) 7$ & كم كردن نمك غذا & 11 \\
\hline \multicolumn{2}{|c|}{$(r\urcorner) \leqslant 0$} & $(Y O / 7) r T$ & $(Y / / \Lambda) \mu^{\prime}$ & $(9 / 7) \mid r$ & كم كردن مايعات دريافتى & ir \\
\hline \multicolumn{2}{|c|}{$(\varepsilon \varepsilon) 00$} & $(I r / 7) I V$ & $(9 / 7) \mid r$ & $(r T / \Lambda) \varepsilon$ & مصرف يكى قرص اضافى ادرار آور & ir \\
\hline \multicolumn{2}{|c|}{$(0 N / \varepsilon) V r$} & $(r T / \varepsilon) \mu r$ & $(11 / T) \mid \varepsilon$ & (乏) 0 & تماس با يزشك يا مركز & $1 \varepsilon$ \\
\hline خيلى سريع & سريع تشخيص & ديرتشخيص تقريباً سريع & تشخيص & علامتى & با جهه سرعتى تشخيص & \multirow{4}{*}{10} \\
\hline تشخيص دادم & دادم & تشخيص دادم & 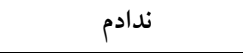 & 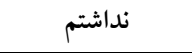 & داديد كه تنكى نفس يا & \\
\hline تعداد(درصد) & تعداد(درصد) & تعداد(درصد) تعداد(درصد) & تعداد (درصد) & تعداد (درصد) & ورم پاى شما به علت & \\
\hline$(\Sigma T / \varepsilon) 01$ & $(1 \Lambda / \varepsilon) r \mu$ & $(I Y / \Lambda) 17 \quad(Y / \varepsilon) r$ & $\left(r_{\cdot}\right)$ YO & $\left(r_{\cdot}\right) Y_{0}$ & بيمارىنارسايىقلبى است؟ & \\
\hline خهلى مطمئنم & مفيد مفئم كه & تا حدى مطمئن مفيد بود & مطئن نيستم مفيد & هيج كارى نكردم & كه دجار مشكل تنفسى بـ آخرين بارى & \\
\hline تعداد(درصد) & تعداد(درصد) & تعداد (درصد) & تعداد (درصد) & تعداد (درصد) & يا ورم قوزى پٍا شديد و & \\
\hline$(\varepsilon 0 / 7)$ or & $(r / / 7) Y V$ & $(I T / \Lambda) 17$ & $(11 / T) \mid \varepsilon$ & $(\Lambda / \Lambda) \|$ & 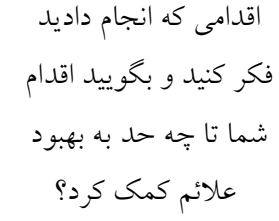 & 17 \\
\hline
\end{tabular}


"كاملا مطمئن هستم" دادند كه دلالت بر اطمينان بالاى آنها به انجام خودمر اقبتى داشت (جدول شماره 0).
در ارتباط با بررسى كويهها در زيرمقياس اطمينان به انجام

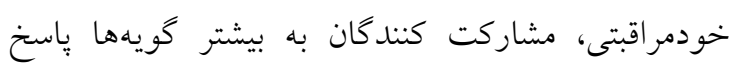

جدول شماره 0: توزيع فراوانى ياسخ به تويههاى زيرمقياس اطمينان به انجام خودمراقبتى

\begin{tabular}{|c|c|c|c|c|c|}
\hline كاملامطمئن & خيلى مطمئن & تا حدى مطمئن & مطمئن & كويه & رديف \\
\hline 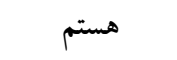 & 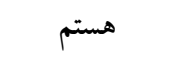 & 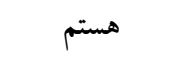 & نيستم & در كل تا جه حد مطمئند كه شما مى توانيد.... & \\
\hline تعداد (درصد) & تعداد (درصد) & تعداد (درصد) & تعداد (درصد) & & \\
\hline (OY) 70 & $(T / / \pi) r q$ & $(10 / r) 19$ & $(9 / 7) I T$ & هميشه علائم نارسايى قلبى را كنترل كنيد؟ & iv \\
\hline$(V \varepsilon / \varepsilon) q r$ & $(1 T / \Lambda) Y 1$ & $(7 / \varepsilon) \wedge$ & $(r / 2) r$ & از دستورات يزشكى ييروى كنيد؟ & 11 \\
\hline$(70 / 7) \wedge r$ & $(r / r) r q$ & $(\Lambda / \Lambda) 11$ & $(r / \varepsilon) r$ & ميزان اهميت علائم نارسايى قلبى را ارزيابى كنيد؟ & 19 \\
\hline$(77 / \varepsilon) \wedge r$ & $(r \cdot / \Lambda) \Gamma T$ & $(\Lambda / \Lambda) 11$ & 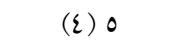 & تغييرات ايجاد شده در وضعيت سلامتيتان را تشخيص دهيد؟ & r. \\
\hline (7.) $\vee_{0}$ & $(T / / T) T V$ & (IT) 10 & $(7 / \varepsilon) \wedge$ & اقدامات درمانى لازم براى بهبود علائم نارسايى قلبى مثل ورم & rI \\
\hline (07) $\mathrm{V} \cdot$ & $(T / T) r q$ & $(17 / \Lambda) r 1$ & 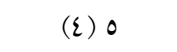 & ارزيابى كنيد كه يك اقدام درمانى تا جههدبراى شماففيداست؟ & rr \\
\hline
\end{tabular}

محمدى و همكاران نيز نشان داد وضعيت خودمراقبتى بيماران مبتلا به نارسايى قلبى، در سطح متوسط است (عَr.r.).

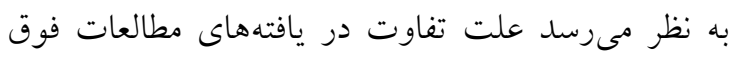

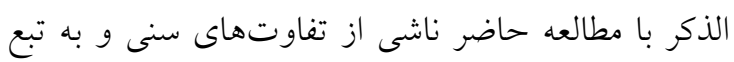

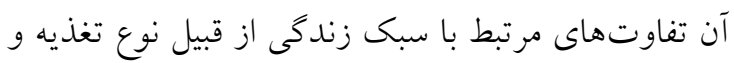

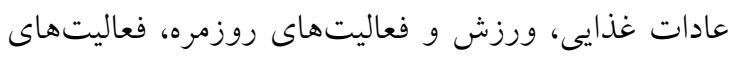

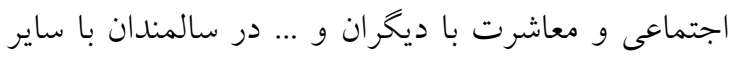

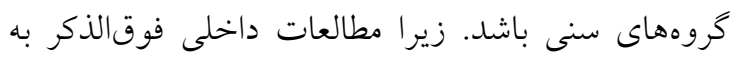
بررسى خودمر اقبتى در بيماران مبتلا به نارسايى قلبى بطور

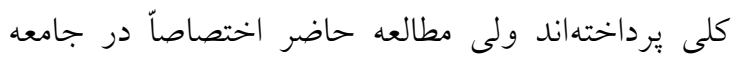
سالمندان مبتلا به نارسايى قلبى انجام شده است. همجنِين اين تفاوتها مىتواند بدليل تفاوت در ابزارهاى بررسى

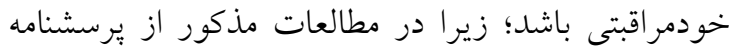
مقياس ارويايى رفتار خودمر اقبتى در بيماران نارسايى قلبى EHFSCB:European Heart Failure Self) (Care Behavior Self-Care of Heart) SCHFI مطالعه حاضر از ابزار Failure Index ) استفاده شده است و اخر جهه هر دو ابزار خودمراقبتى را مورد سنجش قرار مىدهند، ولى طراحى،

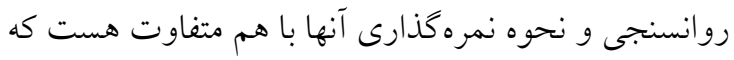
مى تواند تفسير نتايج را تحت تأثير قرار دهد.

\section{بحث و نتيجه كيرى}

اين مطالعه با هدف تعيين وضعيت خودمراقبتى در ابعاد

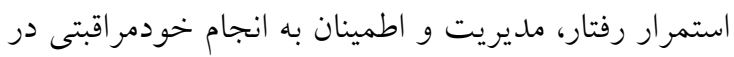
سالمندان مبتلا به نارسايى قلبى بسترى در بيمارستانهاى رئاى دولتى شرق كيلان انجام شد. يافتهها نشان داد كه بيشتر واحدهاى يزوهش از نظر خودمراقبتى كل و زير مقياس هاى آن داراى وضعيت مطلوب بودند بروند

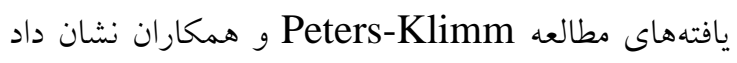

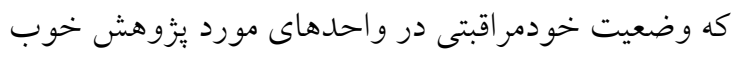
بود (ra). در مطالعه باقرى نسامى و همكاران كه با هدف وند

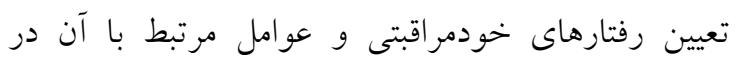
سالمندان ساكن منازل شهرستان سارى انجام شد شئ نيز

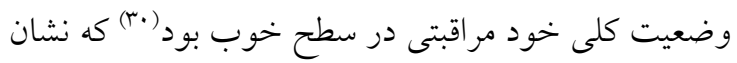
دهنده همسويى نتايج مطالعه حاضر با اين مطالعات است.

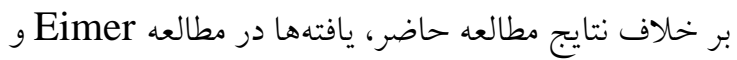
همكاران، وضعيت خودمر اقبتى سالمندان مبتلا به نارسايى

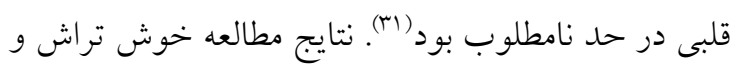
همكاران، مؤدب و همكاران، شجاعى و همكاران، Vidán

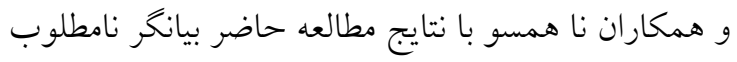
بودن وضعيت خودمراقبتى در سالمندان مبتلا به نارسايى

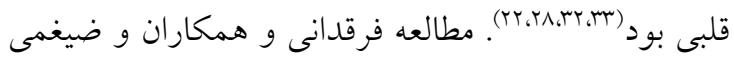


انجام شد و نشان داد تنها سب درصد بيماران از برنامه رزيم غذايى كم سديم بيروى مى كردند (rV) همسو نيست. در مطالعه حاضر كمترين رفتارهاى خود مراقبتى مربوط به ليه

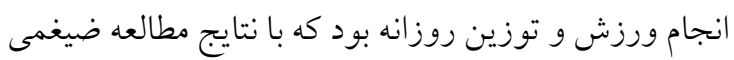
محمدى و همكاران، خوش تراش و ابوطالبى (ع.r.rrr) مطابقت دارد. مطالعه شجاعى و همكاران نيز نشان داد كه درصد قابل توجهى از بيماران نارسايى قلبى هيج نوع

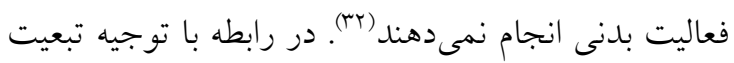
كمتر بيماران مبتلا به نارسايى قلبى نسبت به انجام منظم

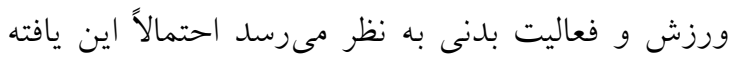
مربوط به تنخى نفس و احساس خستخى در بيماران نارسايى قلبى است كه فعاليت جسمى آنان را محدود مى كند(عَ). در حاليكه بر اساس نظر انجمن قلب نيويورى ز) (NYHA: New York Heart Association) طبقه بندى CHF، غير از بيماران كلاس IV كه علايم در آنها با هر كونه فعاليتى ايجاد مىشوند و حتى در طى استراحت هم ممكن است علايم داشته باشند و نياز به استراحت مطلق دارند، بقيه بيماران مىتوانند فعاليت عادى (كلاس I و II و يا فعاليتهاى مختصر جسمانى (كلاس (III ) را داشته باشند با وجود اين كه توزين روزانه از برنامهاى خود مراقبتى توصيه شده در بيماران نارسايى قلبى است اما اين رفتار حتى در بيماران داراى علائم شديد، كمتر انجام مىشود. يكى از دلايل بىتوجهى به توزين روزانه تصور اشتباه بيماران در اين زمينه است كه كنترل وزن را تنها براى بررسى جاقى در نظر مى گيرند و از كاربرد آن در بررسى

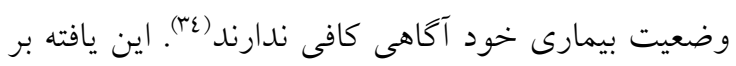
ضرورت توجه به توزين روزانه در برنامههاى آموزشى خود مر اقبتى بيماران تأكيد مىنمايد. نكته قابل توجه در مطالعه حاضر آن بود كه بيشتر مشاركت كندكان فعاليتهاى بدنى روزمره عادى مثل انجام امور منزل را انجام مىدادند ولى ورزش روزانه را انجام نمى دادند. به نظر مىرسد موضوع ورزش نكردن افراد يك مسئله فرهنكى، اجتماعى و اقتصادى است كه الزاماً
يافته ها در مطالعه حاضر بيانكر آن بود كه بهترين وضعيت خودمراقبتى مطلوب به ترتيب در بعد اطمينان به انجام خودمراقبتى، مديريت خودمراقبتى و استمرار خودمراقبتى بود. نتايج مطالعه Tung و همكاران در بيماران مبتلا به نارسايى قلبى در تايوان بيانخر سطح پيايين استمرار و مديريت خودمراقبتى و سطح مطلوب اطمينان مراقبت ازخود بود(ro) كه نشان دهنده همراستايى نتايج مطالعه حاضر از نظر مطلوبترين وضعيت خودمراقبتى در بعد اطمينان با نتايج اين مطالعه است. در مطالعه منصورى و همكاران، مطلوبترين وضعيت خودمراقبتى مربوط به زيرمقياس مديريت خودمراقبتى و كمترين ميانخين در

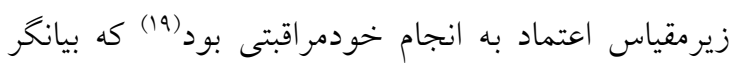
فقدان همخوانى نتايج مطالعه حاضر با نتايج اين مطالعه است. علت تفاوت در نتايج مىتواند ناشى از تفاوت در نمونهاى تحقيق باشد. زيرا جامعه آمارى در مطالعه منصورى و همكاران شامل تمامى بيماران مبتلا به نارسايى قلبى بودند ولى مطالعه حاضر صرفاّ روى سالمندان مبتلا به نارسايى قلبى انجام شده است. به نظر مىرسد درگيرى طولانى مدت با اين بيمارى در طى سالهاى عمر در سالمندان باعث شده است كه آنها تأثيرات روشي لهاى مراقبتى را در خود آزموده و به اعتماد واطمينان كافى از روشهاى خود مراقبى دست يافتهاند. در ارتباط با بررسى گويهها در زيرمقياس استمرار خودمراقبتى، بهترين رفتارهاى خودمراقبى بـه ترتيب مربوط به محافظت از خود براى جلو گيرى از بيمار شدن، رعايت رزيم غذايى كم نمك و مراجعه مرتب به بزشك يا مركز درمانى براى بررسى وضعيت قلب بود. همراستا به له ليه نتايج مطالعه حاضر يافتهها در مطالعه ضيغمى محمدى و همكاران نيز نشان داد بهترين تابعيت رفتارهاى خود مراقبتى مربوط به رزيم دارويى و غذايى بود(عَ). نتايج مطالعه حاضر با نتايج مطالعات خوش تراش و

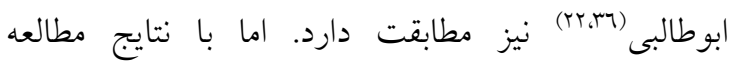
Frediani 


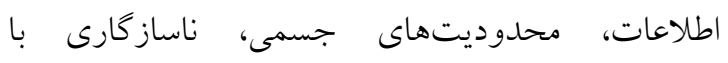

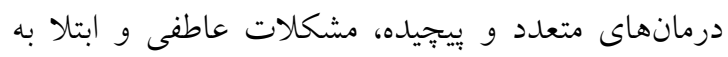

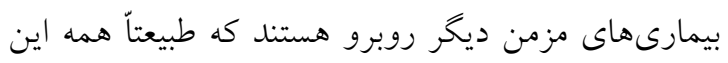

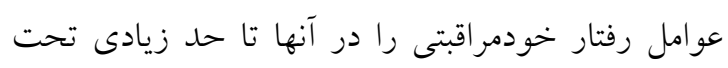
تأثير قرار مى دهد

اعتقاد بر اين است كه نداشتن آكاهى و دانش كم در مورد نارسايى قلبى و كمبود اطلاعات در مورد رفتارهاى خودمراقبتى مرتبط با اين بيمارى و فقدان آموزش به بيماران مىتواند يكى از علل نامطلوب بودن وضعيت

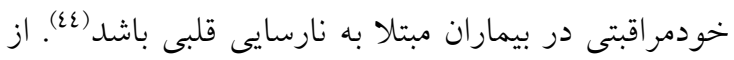

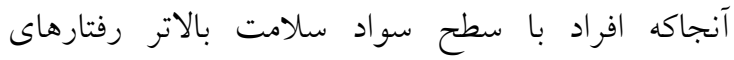
خودمر اقبتى بهترى از خود نشان مىدهند، بنابر اين فرآيند ياد دهى و يادگيرى فعاليتهاى خود مر اقبتى مى تواند فرد

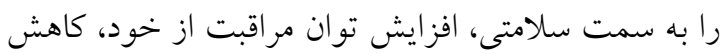

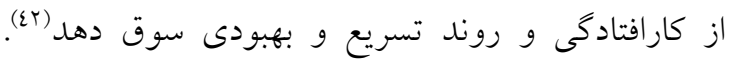

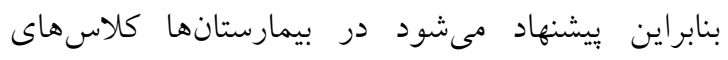

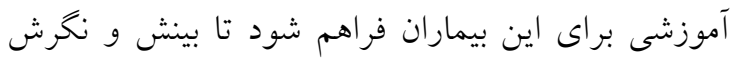

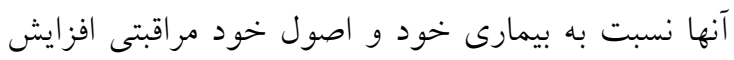
يابد. همجنين، با توجه به اينكه امروزه بيشتر قشر جامعه

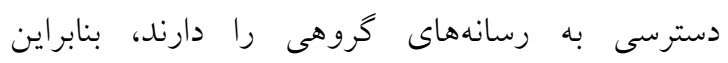

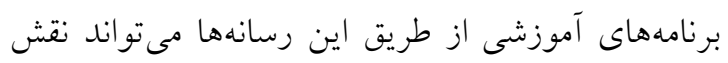

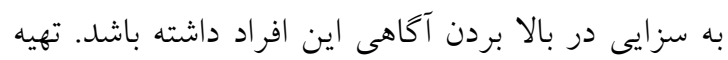

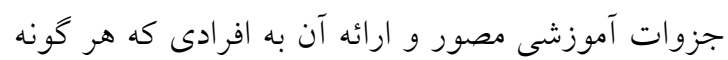
بيمارى قلبى شناخته شده و به ويزه نارسايى قلبى دارند

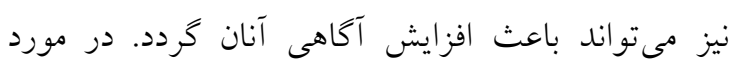
بيماران سالخورده مبتلا به نارسايى قلبى متوسط و شديد، مداخلات تيمى خجند رشتهاى بايد بر حمايت ويزه در مراقبت از خود و خودكنترلى اين بيماران متمركز باشند. اين اقدامات باعث بهينه سازى وضعيت جسمى و بالينى بيمار مىشود. در اين ميان نقش خانواده نيز جهت ايجاد انخيزه و مراقبت از سالمندان ملموس است. از جمله محدوديتهاى يُزوهش حاضر، استفاده از

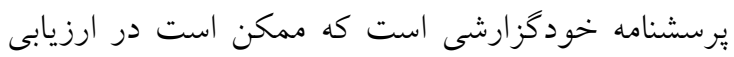
نتايج، تورش خودكزارشى (Self-reporting bias)
اختصاص به سالمندان ندارد و در ساير گروههاى سنى نيز

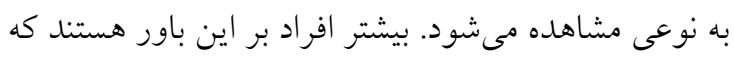
انجام ورزش بايد در باشگاه ورزشى و تحت نظر مربيان

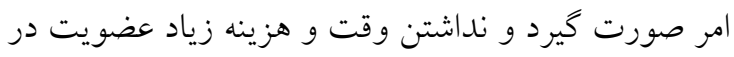

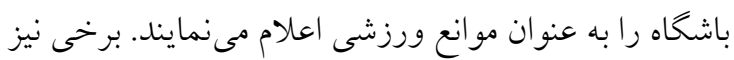

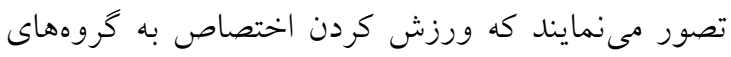
جوان دارد و با افزايش سن انخيزهاى براى انجام آن ندارند. مطالعات كمى و كيفى ييشين دلايل مشاركت كم اين جمعيت در فعاليتهاى بدنى براى بهبود سلامت آنها را نشان

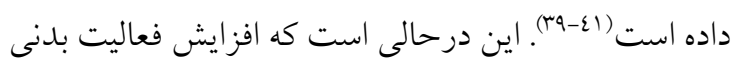
در بيماران نارسايى قلبى با شدت متوسط سبب بهبود تهويه، تغيير يذيرى سرعت ضربان قلب و افزايش جريان خون مىشود به بيماران نارسايى قلبى توصيه مىشود كه •ا تأ ا ماه بعد از ابتلا به نارسايى قلبى •با دقيقه در هفته

فعاليت داشته باشند (r). نكته قابل توجه در يافتههاى مطالعه حاضر در زيرمقياس باس

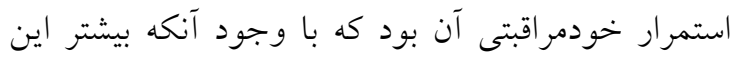

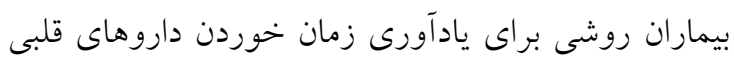

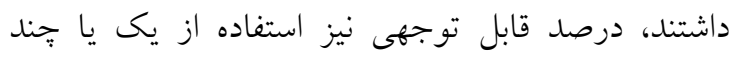

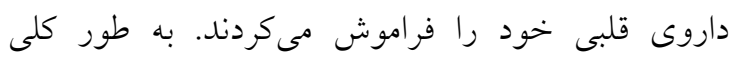

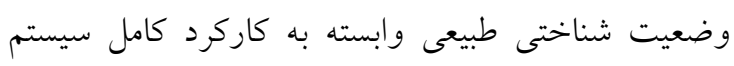

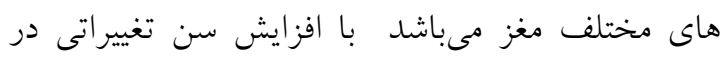

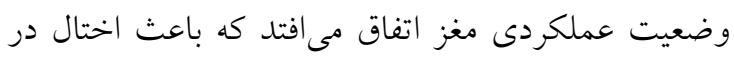

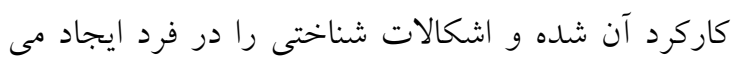
نمايد (10) در كل عوامل زيادى بر انجام رفتارهاى خودمراقبتى مؤثر

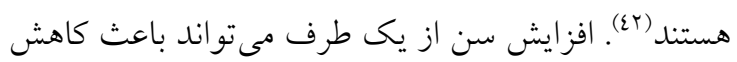
رفتارهاى خودمراقتى و از طرفى شدت بيمارى باعث

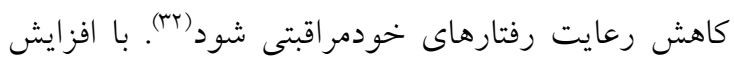

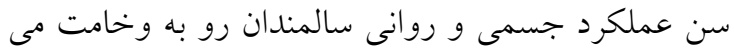
كذارد(צ'). افزايش سن به دلايلى نظير فراموشى، ناتوانى و

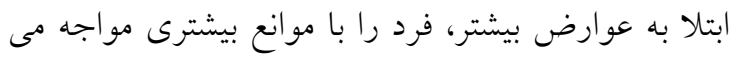

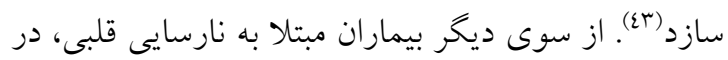
انجام رفتارهاى خودمراقبتى، با موانع متعددى نظير كمبود 


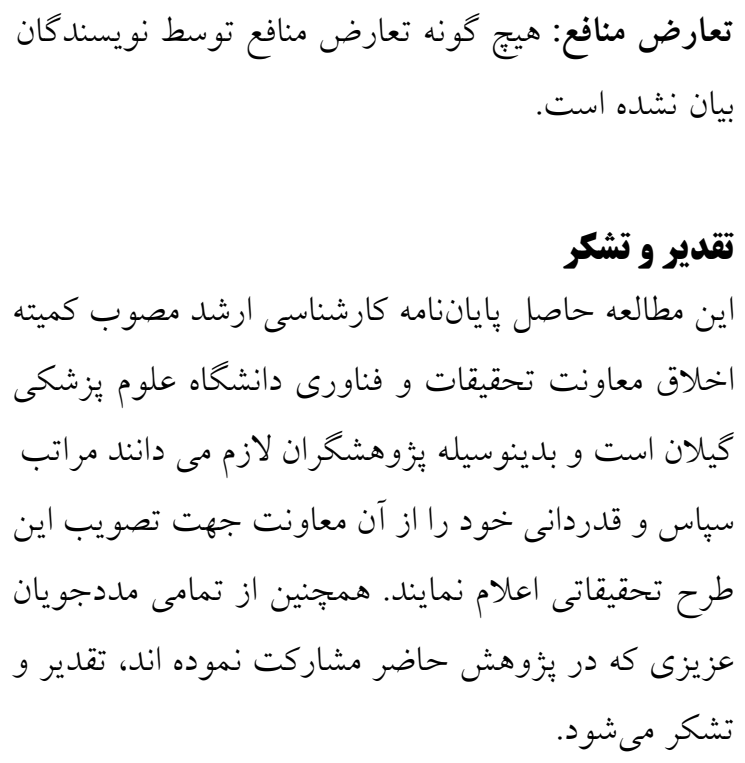

$$
\begin{aligned}
& \text { ايجاد كرده باشد. محدوديت ديخر آن بود كه اين مطالعه به }
\end{aligned}
$$

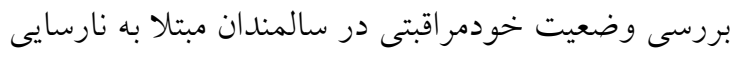

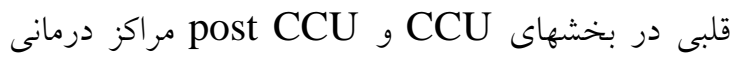

$$
\begin{aligned}
& \text { دولتى شرق كيلان يرداخته است و بنابراين نمى توان نتان نتايج }
\end{aligned}
$$

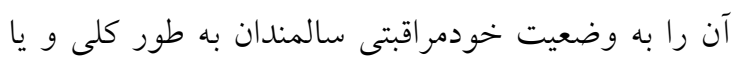

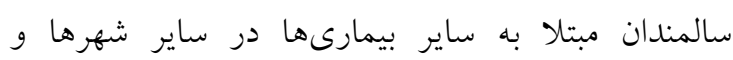

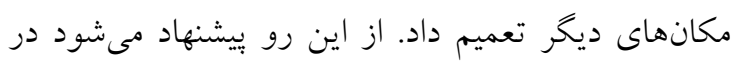

$$
\begin{aligned}
& \text { يزوهششهاى جداءانه وضعيت خودمر اقبتى سالمندان مبتلا } \\
& \text { به ساير بيمارىها نيز انجامشده و نتايج آنها با يكديخر } \\
& \text { مقايسه شود. }
\end{aligned}
$$

\section{References}

1. Ramtin S, Nikpeyma N. Investigating the happiness promotion Strategies in Iranian older adults: a review article. Journal of Gerontology(joge). 2020;4(3):40-55. [Persian]

2. Ramezankhani A, Mohammadi G, Akrami F, Zeinali M. Knowledge, attitude and practice of the elder residents of Tehran city about healthy lifestyle. Journal of Health in the Field. 2013; 1(1):15. [Persian]

3. World Health Organisation. Ageing and health. 2018. Available from: https://www.who.int/newsroom/fact-sheets/detail/ageing-and-

health\#: :text=By\%202050\%2C\%20the\%20world's\%20population,in\%20this\%20age\%20group $\% 20$ worldwide.

4. Baladi Mousavi S. Country's Elderly Status. Available from: URL: https://www.amar.org.ir/Portals/0/News/1396/salmandan.pdf

5. Sargazi M, Salehi S, Sargazi V. Status sdcreening examinations of elderly people admitted to hospital in zahedan. Journal of Holistic Nursing And Midwifery. 2014;24(3):20-6. [Persian]

6. Centers for disease control and merck company foundation. The state of aging and health in America. 2007. Available from https://www.cdc.gov/aging/pdf/saha_2007.pdf

7. Correll CU, Solmi M, Veronese N, Bortolato B, Rosson S, Santonastaso P, Thapa-Chhetri N, Fornaro M, Gallicchio D, Collantoni E, Pigato G. Prevalence, incidence and mortality from cardiovascular disease in patients with pooled and specific severe mental illness: a large-scale metaanalysis of 3,211,768 patients and 113,383,368 controls. World Psychiatry. 2017;16(2):163-80.

8. Tomasoni D, Adamo M, Lombardi CM, Metra M. Highlights in heart failure. ESC heart failure. 2019;6(6):1105-27.

9. Jain S, Kaware AC, Doibale MK, Shaikh S, Radhey BK, Madhuri PM. Morbidity pattern among geriatric population in urban field practice area of district of Maharashtra: a cross sectional study. Int J Comm Medic Public Health. 2016;3(2):523-9.

10. Navidian A, Moradgholi M, Kykhaee A, Saeedinegad F. Relationship between attachment styles and self-care behaviors in patients with heart failure. Hayat. 2015;21(2):6-17. [Persian]

11. Moradi Y, Rahmani A, Aghakarimi K, Sheikhy N. Effect of applying follow-up care model on self-care management in heart failure patients: a randomized clinical trial. Nursing And Midwifery Journal. 2017;15(3):208-17. [Persian]

12. Shahbaz A, Hemmati-Maslakpak M. Relationship of self-care behaviors with hospital readmission in people with heart failure. Iranian Journal of Cardiovascular Nursing. 2017;6(2):24-33. [Persian] 
13. Ghods R, Gorji N, Moeini R, Ghorbani F. Semiology and management of heart failure according to Traditional Persian Medicine views. Complementary Medicine Journal of Faculty of Nursing \& Midwifery. 2017;(22)1:1791-804. [Persian]

14. Navidian A, Mobaraki H, Shakiba M. The effect of education through motivational interviewing compared with conventional education on self-care behaviors in heart failure patients with depression. Patient education and counseling. 2017;100(8):1499-504. [Persian]

15. Mansouriyeh N, POURSHARIFI H, TABAN SM, SEIRAFI M. The relationship between socioeconomic status and self-care in patients with heart failure: The role of illness related worries mediator. Journal of Nurse and Physician within War. 2018;5(17):5-12. [Persian]

16. Riegel B, Jaarsma T, Strömberg A. A middle-range theory of self-care of chronic illness. Adv Nurs Sci. 2012;35(3):194-204.

17. Sedlar N, Lainscak M, Mårtensson J, Strömberg A, Jaarsma T, Farkas J. Factors related to self-care behaviours in heart failure: A systematic review of European Heart Failure Self-Care Behaviour Scale studies. Eur J Cardiov Nurs. 2017;16(4):272-82.

18. Jaarsma T, Cameron J, Riegel B, Stromberg A. Factors related to self-care in heart failure patients according to the middle-range theory of self-care of chronic illness: a literature update. Curr Heart Fail Reports. 2017;14(2):71-7.

19. Mansouri KH, Hasavari F, Kazemnejad LE, Gholipour M. Self-care status and its related factors in patients with heart failure. Journal of Health and Care. 2018;19(4):232-41. [Persian]

20. Farghadani Z, Taheri KZ, Amiri MA, Montazeri A. Self-care behaviors and its related factors in patients with heart failure. Payesh. 2018;17(4):371-9. [Persian]

21. Bagheri-Saweh MI, Lotfi A, Salawati Ghasemi S. Self-care behaviors and related factors in chronic heart failure patients. Int J Biomedic Public Health. 2018;1(1):42-7.

22. Salehzadeh A, Rahmatpour P. Self-care behaviors and related factors in patients with heart failure reffering to medical \& educational center of heart in Rasht. Journal of Holistic Nursing And Midwifery. 2013;23(1):22-9. [Persian]

23. Hinkle JL, Cheever KH. Brunner \& Suddarth's Textbook of Medical-Surgical Nursing. $14^{\text {th }}$ ed. Philadelphia, PA: Lippincott Williams \& Wilkins; 2018.

24. Uchmanowicz I, Wleklik M, Gobbens RJ. Frailty syndrome and self-care ability in elderly patients with heart failure. Clin Interv Aging. 2015;10:871.

25. Rahmani M, Darvishpour A, Pourghane P. Application of MoCA, MMSE and AMTs tests in diagnosing the cognitive status of the elderly under hemodialysis in Medical centers of Guilan University of Medical Sciences in 2019. Journal of Gerontology (JOGE). 2020;5(3):64-76. [Persian]

26. Narimani M, Sharbati A. Comparison of anxiety sensitivity and cognitive function in students with and without dysgraphia. Journal of Learning Disabilities. 2015;4(4):85-100. [Persian]

27. Riegel B, Carlson B, Moser DK, Sebern M, Hicks FD, Roland V. Psychometric testing of the selfcare of heart failure index. Journal of cardiac failure. 2004;10(4):350-60.

28. Fatemeh M, Atefeh G, Arsalan S, Ehsan K, Mitra SS, Ezzat P. Study Status Of Self-Care Behaviors And Gender Differences In Patients With Heart Failure. Payavard Salamat. 2014;8(3):220-34. [Persian]

29. Peters-Klimm F, Freund T, Kunz CU, Laux G, Frankenstein L, Müller-Tasch T, Szecsenyi J. Determinants of heart failure self-care behaviour in community-based patients: a cross-sectional study. Eur J Cardiov Nurs. 2013;12(2):167-76.

30. Bagheri Nesami M, Ardeshiri M, Holari B. Self-care behavior and its related factors in the community-dwelling elderlies in Sari, 2014. Journal of Clinical Nursing and Midwifery. 2016;4(4):48-56. [Persian]

31. Eimer S, Mahmoodi-Shan GR. Self-care Behaviour of the Elderly with Heart Failure and its Associated Factors in Hospitals of Gonbad Kavus in 2018. Journal of Research Development in Nursing \& Midwifery. 2020;17(1):12-21. [Persian]

32. Shojaei F, Asemi S, NAJAF YA, Hosseini F. Self-care behaviors in patients with heart failure. Payesh. 2009;8(4):361-9. [Persian]

33. Vidán MT, Sánchez E, Fernández-Avilés F, Serra-Rexach JA, Ortiz J, Bueno H. FRAIL-HF, a study to evaluate the clinical complexity of heart failure in nondependent older patients: rationale, methods and baseline characteristics. Clinical cardiology. 2014;37(12):725-32. 
34. Zeighami Mohamadi S, Alhani F, Shakoor M, Farmani P, Mohseni B, Fallah Taherpazir E. Selfcare behaviors in patients with systolic heart failure. Journal of Nursing and Midwifery Sciences. 2015;2(1):46-54. [Persian]

35. Tung HH, Chen SC, Yin WH, Cheng $\mathrm{CH}$, Wang TJ, Wu SF. Self care behavior in patients with heart failure in Taiwan. Eur J Cardiov Nurs. 2012;11(2):175-82.

36. Daryasari GA, Karkezloo NV, Mohammadnejad E, Vosooghi MN, Kagi MA. Study of the self-care agency in patients with heart failure. Iran J Crit Care Nurs. 2012;4:203-8. [Persian]

37. Frediani JK, Reilly CM, Higgins M, Clark PC, Gary RA, Dunbar SB. Quality and adequacy of dietary intake in a southern urban heart failure population. J Cardiov Nurs. 2013;28(2):119-28.

38. Fletcher B, Magyari P, Prussak K, Churilla J. Physical training in patients with heart failure. Revista Médica Clínica Las Condes. 2012;23(6):748-55.

39. Lattimore D, Wilcox S, Saunders R, Griffin S, Fallon E, Hooker S, Durstine JL. Self-reported barriers of middle-aged and older adults entering a home-based physical activity program. Califor J Health Prom. 2011;9(2):15-28.

40. Gothe NP, Kendall BJ. Barriers, motivations, and preferences for physical activity among female African American older adults. Gerontol Geriat Medic. 2016;(2)2:1-8.

41. Moschny A, Platen P, Klaaßen-Mielke R, Trampisch U, Hinrichs T. Barriers to physical activity in older adults in Germany: a cross-sectional study. Int J Behav Nutr Physical Activ. 2011;8(1):1-10.

42. Sabourian Jouybari S, Jafari H, Mirani SH, Motlagh F, Goudarzian AH. Investigating Self-care behavior in patients with heart failure. Journal of Mazandaran University of Medical Sciences. 2015;25(130):200-1. [Persian]

43. Fallah Tafti B, Vaezi AA, Moshtagh Z, Shamsi F. The assessment of barriers to the self-care behaviors in type 2 diabetic patients of Yazd province in 2014. Tolooebehdasht. 2016;15(3):11529. [Persian]

44. Zamanzadeh V, Valizadeh L, Jamshidi F, Namdar H, Maleki A. Self-care behaviors among patients with heart failure in Iran. Journal of caring sciences. 2012;1(4):209-14. [Persian] 